\title{
TERAPI HERBAL BAGI LANSIA DENGAN HIPERTENSI
}

\author{
Anung Ahadi Pradana ${ }^{*}$, Intan Kurniawati Pramitaningrum ${ }^{2}$ \\ 1. Program Studi DIII Keperawatan, STIKes Mitra Keluarga, Bekasi-Indonesia \\ 2. Program Studi DIII Analis Kesehatan, STIKes Mitra Keluarga, Bekasi-Indonesia
}

*Korespondensi: Anung Ahadi Pradana | STIKes Mitra Keluarga | ahadianung@ gmail.com

\begin{abstract}
Abstrak
Pendahuluan: Angka kejadian hipertensi pada lanjut usia di Indonesia menjadi salah satu penyebab penurunan kualitas hidup dan berkontribusi tinggi dalam peningkatan kebutuhan akan pelayanan kesehatan. Pemanfaatan terapi herbal bagi lansia dengan hipertensi dapat menjadi salah satu intervensi yang dapat diberikan oleh tenaga kesehatan.

Metode Penulisan artikel ini menggunakan teknik studi literatur untuk merangkum beberapa terapi herbal yang dapat dipergunakan bagi lansia yang mengalami hiperensi.

Hasil: Hasil yang ditemukan antara lain beberapa tanaman herbal yang dapat ditemukan di Indonesia sudah teruji memiliki efek positif terhadap penurunan tekanan darah pada lansia.

Kesimpulan: Perhatian pemerintah terhadap pemanfaatan tanaman herbal di Indonesia diketahui cukup tinggi, hal ini terlihat dari cukup banyaknya peraturan yang mengatur tentang penggunaan tanaman herbal dalam aktivitas promotif, preventif, rehabilitatif, maupun kuratif pada lansia khususnya yang mengalami hipertensi.
\end{abstract}

Kata Kunci: Hipertensi, Lanjut usia, Terapi herbal.

Diterima 20 September 2020; Accepted 30 Desember 2020

\section{PENDAHULUAN}

Jumlah lanjut usia di Indonesia mengalami pertumbuhan yang signifikan selama beberapa tahun terakhir, data yang dirangkum dari Infodatin Lanjut usia tahun 2016 menyebutkan bahwa peningkatan persentase penduduk lanjut usia Indonesia mengalami peningkatan pada tahun 2013 sebesar 8,9\% berlanjut menjadi 21,4\% pada tahun 2050 dan $41 \%$ di tahun 2100 (Kementerian Kesehatan RI, 2016). Proses menua sebagai penyebab penurunan fungsi tubuh yang terjadi pada lanjut usia sebagai konsekuensi meningkatnya usia harapan hidup pada suatu masyarakat. Kondisi ini akan berimbas kepada peningkatan angka morbiditas khususnya berbagai penyakit degeneratifdapat menyertai. Penyakit degeneratif menjadi salah satu faktor penghambat utama yang dapat menyebabkan lansia menjadi tidak produktif dan mandiri dimana diantaranya adalah hipertensi (Ferriet al, 2017).

Hipertensi merupakan penyakit tidak menular yang menjadi salah satu penyebab utama kematian prematur di dunia. Organisasi Kesehatan Dunia (WHO) mengestimasikan saat ini prevalensi hipertensi secara global sebesar 22\% dari total penduduk dunia. Asia Tenggara berada di posisi ke-3 tertinggi dengan prevalensi sebesar 25\% terhadap total penduduk.(Kementrian Kesehatan Republik Indonesia, 2019). Prevalensi hipertensi di Indonesia sebesar $34.11 \%$ dengan 3 provinsi tertinggi ditempati Kalimantan Selatan 44.3\%, Jawa Barat 39.6\%, dan Kalimantan Timur 39.3\%. Sementara prevalensi lansia yang mengalami hipertensi di Indonesia mengalami peningkatan jika dilihat berdasarkan perbandingan antara survey riset kesehatan dasar 2013 dan 2018, hal ini dapat terlihat dari adanya peningkatan jumlah penderita hipertensi pada usia 55-64 tahun sebesar 9.3\%, usia 65-74 sebesar 5.6\%, dan 5.7\% pada usia $>75$ tahun (Kementerian Kesehatan RI, 2018). Kondisi hipertensi yang terjadi pada lansia di Indonesia diketahui dapat dicegah melalui beberapa intervensi baik yang bersifat medis-konvensional hingga komplementeralternatif.

Pengobatan Komplementer-Alternatif adalah pengobatan non konvensional yang ditujukan untuk meningkatkan derajat kesehatan masyarakat meliputi upaya promotif, preventif, kuratif, dan rehabilitatif yang diperoleh melalui pendidikan terstruktur dengan kualitas, keamanan, dan efektifitas yang tinggi yang berlandaskan ilmu pengetahuan biomedik, yang belum diterima dalam kedokteran konvensional (Kementrian Kesehatan Republik Indonesia, 2010).Masyarakat Indonesia sudah sejak zaman dahulu kala menggunakan ramuan obat tradisional Indonesia sebagai upaya pemeliharaan kesehatan, pencegahan penyakit, dan perawatan kesehatan. Ramuan obat tradisional Indonesia tersebut dapat berasal dari tumbuhan, hewan, dan mineral, namun umumnya yang digunakan berasal dari tumbuhan (Kementrian Kesehatan Republik Indonesia, 2007). 
Perkembangan pelayanan kesehatan tradisional menggunakan ramuan ini kian pesat, terbukti dari hasil Riset Kesehatan Dasar (Riskesdas) 2018 bahwa persentasependuduk Indonesia yang pernah mengonsumsi jamu sebanyak 59,12 \% yang terdapat pada kelompok umur di atas 15 tahun (Kementrian Kesehatan Republik Indonesia, 2017), dan beberapa tanaman herbal dari indonesia diketahui memiliki manfaat dalam memberikan efek positif terhadap penurunan tekanan darah individu (Sulistyowati et al., 2017). Berdasarkan hal tersebut, penulis bertujuan untuk menjelaskan beberapa terapi herbal yang memiliki efek positif terhadap penurunan hipertensi pada lansia.

\section{METODE}

Penulisan ini bertujuan untuk merangkum beberapa terapi herbal yang dapat dipergunakan untuk menurunkan hipertensi pada lansia di Indonesia menggunakan metode studi literatur sederhana.Pencarian artikel bersumber dari artikel nasional didapatkan dari beberapa database diantaranya Science and Technology Index (SINTA) dan Google Scholar antara tahun 2010 hingga 2020.Kata kunci yang dipergunakan merupakan gabungan dan kombinasi dari beberapa kata, antara lain "Terapi Herbal", "Hipertensi", dan "lansia". Total artikel terkait kata kunci yang didapatkan sebanyak 34 artikel jurnal. Kriteria inklusi yang dipergunakan antara lain : (1) artikel berbahasa Indonesia, (2) memuat artikel hubungan terapi herbal terhadap hipertensi pada lansia, (3) memuat artikel dengan desain original research.

\section{HASIL}

Berdasarkan hasil penelusuran, didapatkan hasil terdapat beberapa terapi herbal yang memiliki implikasi positif terhadap penurunan tekanan darah pada lansia. Adapun terapi herbal yang penulis temukan sebagai berikut:

\section{A. Tomat (Solanum lycipersicum)}

Tomat (Solanum lycopersicum) merupakan sumber vitamin dan mineral (Wasonowati, 2011). Buah tomat dianggap sebagai salah satu sumber terbaik akan produksi likopen, selain mengandung vitamin A dan $\mathrm{C}$ yang cukup tinggi. Buah tomat mengandung likopen $30-200 \mathrm{mg} / \mathrm{kg}$ segar, 3 - $5 \mathrm{mg} / \mathrm{L}$ (Hasri, 2017). Selain likopen, tomat juga menjadi sumber kalium, asam folat, vitamin A, C, E, dan serat yang dapat membantu menurunkan tekanan darah.Tomat matang juga mengandung zat gizi bioaktif seperti tocopherols, phenolics, glycoalkaloids, dan flavonoids. Penelitian di Selandia Baru menunjukkan bahwa kulit dan biji tomat memberikan kontribusi 53\% total phenolics, 52\% total flavonoids, $48 \%$ total likopen, dan $43 \%$ total asam askorbat (Aiska and Kusumastuti, 2014). Cara pembuatan sebanyak 150 gram buah tomat matang, air sekitar $50 \mathrm{ml}$, ditambahkan gula maupun tidak, kemudian dihancurkan dengan menggunakan blender. Pemberian dilakukan sebanyak $1-2$ kali dalam sehari, dilakukan terus menerus selama 7 - 14 hari(Kementrian Kesehatan Republik Indonesia, 2017).

\section{B. Seledri (Apium graveolens)}

Seledri diketahui mengandung zat flavonoid, saponin, tannin $1 \%$, minyak atsiri $0,033 \%$, flavorglukosida (apiin), apigenin, kolin, lipase, asparagin, zat pahit, vitamin (A,B,C). Setiap $100 \mathrm{~g}$ herba seledri mengandung air $93 \mathrm{ml}$, protein $0,9 \mathrm{~g}$, lemak $0,1 \mathrm{~g}$, karbohidrat $4 \mathrm{~g}$, serat $0,9 \mathrm{~g}$, kalsium $50 \mathrm{mg}$, besi $1 \mathrm{mg}$, fosfor $40 \mathrm{mg}$, yodium $150 \mathrm{mg}$, kalium $400 \mathrm{mg}$, magnesium $85 \mathrm{mg}$, vitamin A $130 \mathrm{IU}$, vitamin C $15 \mathrm{mg}$, riboflavin $0,05 \mathrm{mg}$, tiamin $0,03 \mathrm{mg}$, nikotinamid $0,4 \mathrm{mg}(\mathrm{Jun}$ and Yunhui, 2018). Pemberian kepada penderita hipertensi antara lain jika dalam sediaan ekstrak herbal $3 \times 1$ tablet/hari. atau rebus 40 gram daun seledri dengan air $400 \mathrm{ml}$ menjadi $200 \mathrm{ml}$ dan diberikan 2x dalam sehari selama 1 minggu(Kementrian Kesehatan Republik Indonesia, 2017).

\section{Daun Salam (Syzygium polyanthum)}

Daun salam memiliki banyak manfaat untuk kesehatan antara lain: untuk mengobati diabetes melitus, gastritis, pruritus, diare, mabuk akibat alkohol dan hipertensi (Andoko, 2016). Daun salam adalah salah satu dari jenis terapi herbal yang dapat mengatasi berbagai penyakit yaitu salah untuk penyakit hipertensi, selain mudah didapat daun salam ini juga sering dijumpai dan harganya juga yang relatif murah daun salam ini ternyata juga mempunyai segudang manfaat yaitu dapat menjadi obat maag, diare, menurunkan kadar gula (Diabetes Militus), menurunkan kadar kolestrol serta asam urat (Hidayat et al, 2013). Menurut penelitian Hidayat, Hasanah, dan Susanti (2013)pemberian terapi daun salam diberikan dalam bentuk rebusan 5-10 lembar salam/200 $\mathrm{ml}$ dan dikonsumsi sebanyak 2 kali sehari pagi dan sore masing-masing 
100 ml(Kementrian Kesehatan Republik Indonesia, 2017).

\section{Madu}

Madu memiliki banyak manfaat meliputi antioksidan, antimikroba, meningkatkan respon sistem imun, memberikan efek hipotensi, regulasi glikemik dan tidak menimbulkan efek samping (Ajibola et al, 2012). Madu memiliki kandungan penting yang dapat mempengaruhi aktivitas antioksidan yaitu glukosa oksida, katalase, asam askorbik, flavonoid, asam fenolik, karotenoid derivat, asam organik (Bogdanov et al., 2010).Mengonsumsi madu dapat memberikan efek menurukan tekanan darah dengan memberikan $20 \mathrm{ml}$ madu dan diukur tekanan darah setelah 15, 30 dan 60 menit setelah pemberian madu(Aluko, 2013). Madu memiliki komponen kimia yang memiliki efek koligemik yakni zat asetil kolin.Asetil kolin berfungsi untuk melancarkan peredaran darah dan menurunkan tekanan darah. Selain itu dalam madu memberikan efek antioksidan karena di dalamnya mengandung phenol dan flavonoid yang berfungsi sebagai pelindung terhadap masalah pembuluh kapiler dan arterosklerosis (Aden, 2010).

\section{E. Daun Alpukat (Persea americana)}

Daun alpukat bermanfaat membantu menurunkan tekanan darah dengan mengeluarkan sejumlah cairan dan elektrolit maupun zat-zat yang bersifat toksik. Dengan berkurangnya jumlah air dan garam di dalam tubuh maka pembuluh darah akan longgar sehingga tekanan darah perlahan-lahan mengalami penurunan (Kartika et al., 2010).

Daun alpukat setengah tua berwarna hijau mengkilat dikeringkan lalu direbus sebanyak 3 lembar sedangkan daun alpukat yang berukuran kecil 5 lembar ( $25 \mathrm{gr})$ direbus dengan 3 gelas air, atau dengan $750 \mathrm{ml}$ hingga air menjadi \pm 2 gelas, atau $150 \mathrm{ml}$.Rebusan daun alpukat dapat menurunkan tekanan darah pada penderita hipertensi kurang lebih dalam waktu 1 minggu. Air rebusan daun alpukat dikonsumsi 1-2 kali sehari (pagi dan sore hari) dengan dosis 1 gelas 100-150cc(Kementrian Kesehatan Republik Indonesia, 2017).

\section{F. Mengkudu (Morinda citrifolia)}

Mengkudu memiliki berbagai efek terapeutik seperti antiviral, antibakteri, antijamur, antitumor, anthelmintik, analgesik, hipotensi, antiinflamasi, efek peningkatan kekebalan tubuh, mencegah penurunan kolesterol dalam tubuh, zat antihipetensi yaitu zat scopoletin berfungsi mencegah pembentukan plak (aterosklerosis) serta dapat menurunkan tekanan darah (Safitri and Ismawati, 2018).

Buah mengkudu mengandung senyawa kimia yang sangat bermamfaat bagi manusia, yaitu mengandung alkaloid triterpenoid, damnacanthal, pro-xeronine, methoxy, formyl, hydyanthraquinone.Selain kandungan kimia mengkudu juga mengandung minyak menguap asam capron, asam caprylat, moridan dan soranjidiol. Moridon merupakan zat warna merah dan berkhasiat sebagai pencahar, soranjidiol berkasiat sebagai peluruh kencing dan memiliki sifat farmakologis dan diuretik karena kandungan airnya yang tinggi sehingga membantu menurunkan tekanan darah (Sari et al., 2018).

Dosis Pemberian : Pada penderita hipertensi yang mendapatkan terapi jus mengkudu 2 kali sehari yaitu pada 20-30 menit sebelum sarapandan 20-30 menit sebelum makan malam didapatkan penurunan tekanan darah. (Sari, 2015)

\section{G. Bawang Putih (Allium sativum linn)}

Bawang putih dapat menurunkan kadar kolesterol yang terkandung dalam bahan makanan yang mengandung lemak.kandungan kimia dari umbi bawang putih per 100 gram adalah: Alisin 1,5\% merupakan komponen penting dengan efek antibiotik, Protein sebesar 4,5 gram, Lemak 0,20 gram, Hidrat arang 23,10 gram, Vitamin B 1 0,22 miligram, Vitamin C 15 miligram, Kalori 95 kalori, Posfor 134 miligram, Kalsium 42 miligram, Zat besi 1 miligram, Air 71 gram. Di samping itu dari beberapa penelitian umbi bawang putih mengandung zat ajoene yang berfungsi sebagai senyawa yang bersifat antikolesterol dan membantu mencegah penggumpalan darah(Untari, 2010). Dosis per hari untuk menurunkan hipertensi, yaitu sebanyak 600-900 mg per hari dalam bentuk ekstrak, atau $4 \mathrm{~g}$ bawang putih segar per hari, atau $8 \mathrm{mg}$ minyak Allium sativum per hari. Ekstrak bawang putih bubuk dalam dosis 800-900 mg per hari dapat menurunkan tekanan darah sistolik dan diastolik secara bermakna(Kementrian Kesehatan Republik Indonesia, 2017). 


\section{PEMBAHASAN}

Berdasarkan hasil penelusuran terhadap artikel yang didapat oleh penulis, manfaat dari beberapa terapi herbal dapat terlihat sebagai berikut:

\section{A. Tomat (Solanum lycipersicum)}

Dari hasil seluruh artikel yang ditelaah, dapat dikatakan bahwa buah tomat efektif dalam menurunkan tekanan darah tinggi pada pasien dengan penyakit Hipertensi.Tomat mempunyai kandungan seperti likopen yang efektif untuk menurunkan kolesterol, betakaroten dan vitamin E sebagai antioksidan yang dapat mencegah aglutinasi darah.Selain likopen, tomat juga menjadi sumber kalium, asam folat, vitamin A, C, E, dan serat yang dapat membantu menurunkan tekanan darah.Kalium dalam jus tomat menurunkan tekanan darah sistolik dan diastolik dengan menghambat pelepasan renin sehingga terjadi peningkatan ekskresi natrium dan air.Kalsium memiliki efek natriuretik dan berpengaruh dalam menurunkan tekanan darah pada pasien hipertensi. Magnesium merupakan vasodilator dalam pengaturan tekanan darah dan juga sebagai inhibitor dari kontraksi otot polos pembuluh darah (Hasibuan et al., 2016).

\section{B. Seledri (Apium graveolens)}

Manfaat seledri telah terbukti secara ilmiah untuk menurunkan tekanan darah. Seledri memiliki kandungan flavonoid apiin dan apigenin (Suryagustina, 2018). Apiin merupakan senyawa dalam herbaseledri yang berfungsi untuk menurunan tekanan darah baik pada tekanan darah sistolik maupun diastolik (Nuryanto, 2012).Seledri merupakan salah satu jenis terapi herbal untuk menangani penyakit hipertensi mengandung apigenin yang sangat bermanfaat untuk mencegah penyempitan pembuluh darah dan tekanan darah tinggi. Selain itu, mengandung pthalides dan magnesium yang baik untuk membantu melemaskan otot-otot sekitar pembuluh darah arteri dan bantu menormalkan penyempitan pembuluh darah arteri. Pthalides dapat mereduksi hormone stres yang dapat meningkatkan darah (Nurwahidah and Jubair, 2019).

\section{Daun Salam(Syzygium polyanthum)}

Daun salam mengandung senyawa yang berfungsi untuk menurunkan tekanan darah tinggi, diantaranya yaitu Saponin, flavonoid, dan tannin. Saponin yang terdapat dalam daun salam berfungsi sebagai antioksidan yang dapat mencegah terjadinya oksidasi sel pada tubuh(Anggraini, 2019). Kandungan flavonoid yang terdapat pada daun salam dapat mencegah penyakit hipertensi dan menurunkan kolesterol pada darah.Menurut Putri \& Sumekar(2017),daun salam juga banyak mengandung triterpen, tannin, polifenol, dan alkaloid serta minyak atsiri yang terdiri dari sequesterpen, lakton dan fenol. Menurut (Asih, 2018) Kandungan senyawa seperti saponin, flavonoid, tanin dan niasin pada daun salam dapat menurunkan kadar trigliserida serum.

\section{Madu}

Kadar antioksidan dalam madu dapat memperbaiki tekanan oksidatif dan menekan atau mengurangi peningkatan tekanan darah.Tekanan oksidatif berperan penting pada keseimbangan mekanisme vasokontriksi dan vasodilatasi. Madu dapat memperbaiki ketahanan peningkatan antioksidan glutathione $S$ transferase (GST) dantotal antioxidant status(TAS) di ginjal. Selain itu, madu juga mengandung nitrogen oksida (NO) yang dapat memicu sekresi insulin untuk mengabsorbsi ion magnesium yang mengakibatkan dilatasi vaskular yang dapat menurunkan tingkat gula dalam darah dan secara bebas dapat mengakibatkan vasodilatasi arteri koroner pada manusia sehingga memberikan efek hipotensi(Aluko, 2013). Madu efektif terhadap penurunan tekanan darah sistolik, tekanan darah diastolik dan heart rate.Hal ini dikarenakan madu mengandung nitrogen oksida (NO) yang dapat memicu sekresi insulin untuk mengabsorbsi ion magnesium yang mengakibatkan dilatasi vaskular yang dapat menurunkan tingkat gula dalam darah dan secara bebas dapat mengakibatkan vasodilatasi arteri koroner pada manusia sehingga memberikan efek hipotensi.Antioksidan dalam madu dapat memperbaiki tekanan oksidatif dan menekan atau mengurangi peningkatan tekanan darah. Tekanan oksidatif berperan penting pada keseimbangan mekanisme vasokontriksi dan vasodilatasi (Ajibola et al, 2012).

\section{E. Daun Alpukat (Persea americana)}

Daun alpukat dapat menurunkan tekanan darah karena mengandung zat flavonoid, saponin dan 
alkaloid. Zat flavonoid mempengaruhi kerja dari Angiotensin Converting Enzyme(ACE) yang menyebabkan vasodilatasi sehingga tahanan resistensi perifer menurun dan dapat menurunkan tekanan darah. Efek lain flavonoid adalah menurunkan retensi air dan garam oleh ginjal, sekresi aldosteron dan Anti Diuretic Hormone(ADH) oleh kelenjar hipopituitari. Sekresi aldosteron yang menurun berefek terhadap penurunan retensi air dan garam oleh ginjal, sedangkan penurunan sekresi ADH menyebabkan penurunan absorbsi air. Penurunan retensi air menyebabkan volume darah menurun, sehingga tekanan darah menurun (Kartika et al., 2010; Irawati, 2015; Margowati et al., 2016)

\section{F. Mengkudu (Morinda citrifolia)}

Mengkudu mengandung senyawa kimia yang sangat bermamfaat bagi manusia, yaitu mengandung alkaloid triterpenoid, damnacanthal, pro-xeronine, methoxy, formyl, hydyanthraquinone. Selain kandungan kimia mengkudu juga mengandung minyak menguap asam capron, asam caprylat, moridan dan soranjidiol. Moridon merupakan zat warna merah dan berkhasiat sebagai pencahar, soranjidiol berkasiat sebagai peluruh kencing dan memiliki sifat farmakologis dan diuretik karena kandungan airnya yang tinggi sehingga membantu menurunkan tekanan darah (Sari et al., 2018).

Kandungan buah mengkudu yang dapat menurunkan tekanan darah adalah Scopoletin, yang berfungsi memperlebar saluran pembuluh darah yang mengalami penyempitan serta melancarkan peredaran darah. Kandungan scopoletin buah mengkudu dalam 1 gram adalah sebesar 290,02 ppm. Scopoletin dapat menurunkan tekanan darah dengan cara menurunkan tahanan atau resistensi perifer. Selain itu Kandungan bahan aktif scopeletindalam mengkudu memiliki fungsi untuk menormalkan tekanan darah dengan adanya efek spasmolitik. Efek spasmolitik ditandai dengan terjadi pelebaran pembuluh darah (vasodilatasi) akibat relaksasi otot polos, efek tersebut serupa dengan cara kerja obat antihipertensi (Sari, 2015).

Berdasarkan penelitianyang dilakukan oleh Suidah(2011) mengenai pengaruh mengkudu terhadap penurunan tekanan darah pada penderita hipertensi di Sidoarjo didapatkan penurunanMAP (Mean ArterialPressure).MAPsebelum diberikan terapi minum mengkudu sebesar $116.2672 \mathrm{mmHg}$ danMAPsetelah diberikan terapi minum mengkudu sebesar $110.3332 \mathrm{mmHg}$. PenurunanMAP responden dalam penelitian ini sebesar $5.934 \mathrm{mmHg}$.Mengkudu dapat dikonsumsi dengan berbagai cara, bisa di jus, di parut, di tumbuk, direbus, dan masih banyak lagi.

\section{G. Bawang Putih (Allium sativum linn)}

Bawang putih memiliki khasiat yang sangat banyak, dalam kandungan allisin yang dapat mencegah atherosklerosis, antikoulagen (menghancurkan pengumpulan darah), menurunkan kolestrol tinggi, dan menambah sistem kekebalan tubuh. Bawang putih digunakan secara tradisional untuk mengobati tekanan darah tinggi, sakit kepala, gangguan pernapasan, ambeyen, sembelit, luka memar, kolestrol, dan yang lain. Berdasarkan penelitian ilmiah bawang putih digunakan untuk anti diabetes, anti hipertensi, dan anti kolestrol(Izzati and Luthfiani, 2017). Sedangkan menurut penelitian (Wijaya, Adinata and Hudyono, 2015)Bawang putih memiliki kandungan sulfur tertinggi dibandingkan jenis bawang lain.Kandungan lain yang harus diperhatikan adalah Allicin. Allicin memiliki efek anti- mikroba yang dapat melawan virus, bakteri dan parasit, juga dapat menurunkan tekanan darah.

\section{KESIMPULAN}

Beberapa tanaman herbal yang dapat ditemukan di Indonesia sudah teruji memiliki efek positif terhadap penurunan tekanan darah pada lansia. Perhatian pemerintah terhadap pemanfaatan tanaman herbal di Indonesia diketahui cukup tinggi, hal ini terlihat dari cukup banyaknya peraturan yang mengatur tentang penggunaan tanaman herbal dalam aktivitas promotif, preventif, rehabilitatif, maupun kuratif pada lansia khususnya yang mengalami hipertensi. Pentingnya tenaga kesehatan mengetahui pemanfaatan tanaman herbal dapat membantu masyarakat awam dalam kaitannya dengan akses informasi kesehatan komplementer.

\section{REFERENSI}

Aden, R. (2010) Manfaat \& Khasiat Madu Keajaiban Sang Arsitek Alam. Yogyakarta: Hanggar Kreator.

Aiska, G. S. and Kusumastuti, A. C. (2014) 'Perbedaan Penurunan Tekanan Darah Sistolik Lanjut Usia Hipertensi Yang Diberi Jus Tomat (Lycopersicum commune) Dengan Kulit Dan Tanpa Kulit', Journal of Nutrition College, 3(1), pp. 158-162. doi: 10.14710/jnc.v3i1.4547. 
Ajibola, A., Chamunorwa, J. P. and Erlwanger, K. H. (2012) 'Nutraceutical values of natural honey and its contribution to human health and wealth', Nutrition \& Metabolism, 9(June 2014). doi: 10.1186/17437075-9-61.

Aluko, E. O. (2013) 'Comparative Study of Effect of Honey on Blood Pressure and Heart Rate in Healthy Male and Female Subjects', British Journal of Medicine and Medical Research, 3(4)(January). doi: 10.9734/BJMMR/2013/4152.

Andoko, D. N. P. (2016) 'Efektifitas Rebusan Daun Salam Terhadap Penurunan Tekanan Darah Pada Penderita Hipertensi', Journal of Holistic Healthcare, 10(2), pp. 1-4.

Anggraini, N. (2019) 'Studi Katalitik Herbal Ekstrak Daun Salam Sebagai Bahan Aktif Menurunkan Tekanan Darah Tinggi'. doi: 10.31227/osf.io/3qwfj.

Asih, S. W. (2018) 'Pengaruh Rebusan Daun Salam Terhadap Penurunan Tekanan Darah Pada Lansia Penderita Hipertensi Di Wisma Seruni Upt Pslu Jember', The Indonesian Journal of Health Science, (September), p. 169. doi: 10.32528/ijhs.v0i0.1543.

Bogdanov, S. et al. (2010) 'Honey for Nutrition and Health: A Review', Journal of the American College of Nutrition, 27(6)(January). doi: 10.1080/07315724.2008.10719745.

Ferri, C., Ferri, L. and Desideri, G. (2017) 'Management of Hypertension in the Elderly and Frail Elderly', High Blood Pressure \& Cardiovascular Prevention. Springer International Publishing. doi: 10.1007/s40292-017-0185-4.

Hasibuan, N. C. et al. (2016) 'Efektivitas Kandungan Kalium dan Likopen yang Terdapat Dalam Tomat ( Solanum lycipersicum ) Terhadap Penurunan Tekanan Darah Tinggi Effectivity of Potassium and Lycopene in Tomato ( Solanum lycipersicum ) to The Decrease of High Blood Pressure', Majority, 5, pp. 124-128.

Hasri (2017) 'Kandungan Likopen Buah Tomat (lycopersicum esculentum 1.) terhadap Waktu dan Suhu Pemanasan', 20(1), pp. 36-47.

Hidayat, S., Hasanah, L. and Susanti, D. H. (2013) 'PENGARUH REBUSAN DAUN SALAM TERHADAP PENURUNAN TEKANAN DARAH PADA LANSIA DENGAN HIPERTENSI', Jurnal Kesehatan 'Wiraraja Medika'.

Hidayat, S., Hasanah, L. and Susantin, D. H. (2013) 'PENGARUH REBUSAN DAUN SALAM TERHADAP PENURUNAN TEKANAN DARAH PADA LANSIA DENGAN HIPERTENS'.

Irawati, N. A. V. (2015) 'ANTIHYPERTENSIVE EFFECTS OF AVOCADO LEAF EXTRACT (Persea americana mill)', Majority, 4, pp. 44-48.

Izzati, W. and Luthfiani, F. (2017) 'Pengaruh Pemberian Air Rebusan Bawang Putih Terhadap Tekanan Darah pada Pasien Hipertensi di Wilayah Kerja Puskesmas Tigo Baleh Kota Bukittinggi', Afiyah, 4(2), pp. $48-54$.

Jun, Z. and Yunhui, L. (2018) 'Significance of detection of specific protein in serum and urine in early diagnosis of diabetic nephropathy', Chinese and Foreign Medical Research, 16(August). Available at: https://core.ac.uk/download/pdf/323960284.pdf.

Kartika, R. M. et al. (2010) 'Pengaruh pemberian seduhan daun alpukat terhadap penurunan tekanan darah pada lansia dengan hipertensi di dukuh peniten dan sinom desa karanganom’, Karya Ilmiah, 3, pp. 1$10 . \quad$ Available at: http://ejournal.stikestelogorejo.ac.id/index.php/ilmukeperawatan/article/view/233/258.

Kementerian Kesehatan RI (2016) 'Situasi lanjut usia (lansia) di Indonesia', InfoDATIN Kemenkes RI.

Kementerian Kesehatan RI (2018) Riset Kesehatan Dasar.

Kementrian Kesehatan Republik Indonesia (2007) Kebijakan Obat Tradisional Nasional. Indonesia.

Kementrian Kesehatan Republik Indonesia (2010) SAINTIFIKASI JAMU DALAM PENELITIAN BERBASIS PELAYANAN KESEHATAN. Indonesia.

Kementrian Kesehatan Republik Indonesia (2017) FORMULARIUM RAMUAN OBAT TRADISIONAL INDONESIA. Indonesia.

Kementrian Kesehatan Republik Indonesia (2019) InfoDATIN Hipertensi. Jakarta: Kementrian Kesehatan RI.

Margowati, S. et al. (2016) 'Efektivitas Pengunaan Rebusan Daun Alpukat Dengan Rebusan Daun Salam Dalam Penurunan Tekanan Darah Pada Lansia', Universty Research Coloquium, pp. 234-248.

Nurwahidah, N. and Jubair, J. (2019) 'Pengaruh Penggunaan Rebusan Seledri terhadap Penurunan Tekanan Darah pada Penderita Hipertensi di Wilayah Kerja Puskesmas Cenggu Tahun 2018', Bima Nursing Journal, 1(1), p. 43. doi: 10.32807/bnj.v1i1.530. 
Putri, T. U. A. and Sumekar, D. W. (2017) 'Uji efektivitas daun salam (Syzygium polyanthum ) sebagai antihipertensi pada tikus galur wistar', Majority, 6(1), pp. 77-81.

Safitri, A. R. and Ismawati, R. (2018) 'Efektifitas Teh Buah Mengkudu Dalam Menurunkan Tekanan Darah Lansia Dengan Hipertensi (Studi di UPTD. Griya Werdha Kota Surabaya Tahun 2018)', Amerta Nutrition, 2(2), p. 163. doi: 10.20473/amnt.v2i2.2018.163-171.

Sari, C. Y. (2015) 'PENGGUNAAN BUAH MENGKUDU (Morinda citrifoliaL.)UNTUK MENURUNKAN TEKANAN DARAH TINGGI', $J$ Majority, 4(3), pp. 34-40.

Sari, I. K. et al. (2018) 'Pengaruh Pemberian Air Perasan Buah Mengkudu (Morinda Citrifolia) Terhadap Penurunan Tekanan Darah Pada Penderita Hipertensi Pengaruh Pemberian Air Perasan Buah Mengkudu (Morinda Citrifolia) Terhadap Penurunan Tekanan Darah Pada Penderita Hipertensi A', Prosiding Seminar Nasional Biology for Life, 7(2), pp. 117-123.

Sulistyowati, E. et al. (2017) 'Indonesian herbal medicine prevents hypertension-induced left ventricular hypertrophy by diminishing NADPH oxidase- dependent oxidative stress', Oncotarget, 8(49), pp. 86784-86798. doi: 10.18632/oncotarget.21424.

Suryagustina, et al (2018) 'Kata Kunci: Hipertensi, Seledri, Tekanan Darah 151', pp. 151-165.

Untari, I. (2010) 'BAWANG PUTIH SEBAGAI OBAT PALING MUJARAB BAGI KESEHATAN', Jurnal Kesehatan, 7(1), pp. 547-554. Available at: http://jurnal.aiskauniversity.ac.id/index.php/gaster/article/view/59/56.

Wasonowati, C. (2011) 'MENINGKATKAN PERTUMBUHAN TANAMAN TOMAT (Lycopersicon esculentum) DENGAN SISTEM BUDIDAYA HIDROPONIK', Agrovigor, 4(1), pp. 21-28.

Wijaya, Adinata, J. and Hudyono, J. (2015) 'Peranan Allicin dari Ekstrak Bawang Putih Pengobatan sebagai Pengobatan Komplemen Alternatif Hipertensi Stadium I', 2015, 42 no. 4(4), p. 303. 